\title{
Under the lens: Dental expert witnesses in Brazil, Croatia, Indonesia, Italy, Saudi Arabia, and the United Kingdom
}

\author{
Sakher AIQahtani, \\ Ivana Čuković Bagić1, \\ Scheila Manica ${ }^{2}$, \\ Evi Untoro ${ }^{3}$, John Rosie ${ }^{4}$, \\ Emilio Nuzzolese ${ }^{5}$ \\ Assistant Professor and Forensic \\ Odontologist, King Saud \\ University, Riyadh, Saudi Arabia, \\ ${ }^{1}$ Full Professor in Paediatric and \\ Preventive Dentistry, School \\ of Dental Medicine, University \\ of Zagreb, Croatia, ${ }^{2}$ Forensic \\ Odontologist, Santa Catarina, \\ Brazil, ${ }^{3}$ Forensic Pathologist, \\ Sentra Medika Hospital, \\ Cibinong, Indonesia, ${ }^{4}$ Forensic \\ Odontologist, Merseyside, UK, \\ ${ }^{5}$ Forensic Odontologist, Bari, Italy
}

\begin{abstract}
The dentists' main job is to restore health and function to the oral cavity. However, dental professionals can also be involved in medico legal activities as forensic odontologists or by being Expert Witnesses (EW) to testify in professional liability cases, car accidents and work-related injuries. When called to act as an expert witness by the Court, the appointed dentist has to combine both biological and technical knowledge with equivalent medicolegal and forensic knowledge. Spontaneous involvement in medico-legal matters without an adequate training and experience can lead to mistakes with irreversible consequences. As an expert witness, the dentist has precise responsibility with civil and/or penal consequences, depending on the national judicial system. Dental Expert Witness, working either privately or appointed by the Court, has defined responsibilities and is subjected to civil or criminal proceedings (depending on the judicial system) if found wanting. Keeping in mind that there are significant differences regarding the requirements of becoming eligible to be a Dental Expert Witness in different legal systems. In this work the authors investigated the Judicial Systems regarding the appointment of Dental Expert Witnesses in Brazil, Croatia, Indonesia, Italy, Saudi Arabia and the United Kingdom (Table 1), in order to marshal knowledge towards harmonization and the attainment of best practice. This premise acknowledges the fact that forensic odontology must encompass the necessity for robust systems of audit and accreditation for it to be accepted as an "evidence based" forensic discipline.Further steps to ensure quality assurance in legal dentistry and forensic odontology training should be considered to prevent the spontaneous involvement of inappropriately trained dentists to become involved in making decisions that are beyond their competence and expertise.
\end{abstract}

Key words: Dental damage evaluation, dental law, expert witness, forensic odontology

\section{Introduction}

$\mathrm{D}$ entists' main job is to restore health and function to the oral cavity. However, dental professionals can also be

\begin{tabular}{|l|c|}
\hline \multicolumn{2}{|c|}{ Access this article online } \\
\hline \multirow{2}{*}{$\begin{array}{l}\text { Website: } \\
\text { www.jfds.org }\end{array}$} & Quick Response Code \\
\hline \multirow{2}{*}{$\begin{array}{l}\text { DOI: } \\
\text { 10.4103/jfo.jfds_104_17 }\end{array}$} & \\
\hline
\end{tabular}

involved in medicolegal activities as forensic odontologists or by being expert witnesses (EWs) to testify in professional liability cases, car accidents, and work-related injuries.

This is an open access journal, and articles are distributed under the terms of the Creative Commons Attribution-NonCommercial-ShareAlike 4.0 License, which allows others to remix, tweak, and build upon the work non-commercially, as long as appropriate credit is given and the new creations are licensed under the identical terms.

For reprints contact: reprints@medknow.com

How to cite this article: AlQahtani S, Bagić IČ, Manica S, Untoro E, Rosie J, Nuzzolese E. Under the lens: Dental expert witnesses in Brazil, Croatia, Indonesia, Italy, Saudi Arabia, and the United Kingdom. J Forensic Dent Sci 2018;10:8-17. 
When called to act as an EW by a court, the appointed dentist has to combine both biological and technical knowledge with equivalent medicolegal and forensic knowledge. ${ }^{[1]}$ Spontaneous involvement in medicolegal matters without an adequate training and experience can lead to mistakes with irreversible consequences. As an EW, the dentist has precise responsibility with civil and/ or penal consequences, depending on the national judicial system. $\cdot^{[2]}$

Dentists should bear in mind the clear distinction between legal dentistry and forensic odontology, as these areas of expertise require different education and training, one related to the national judicial system and the latter related to international standards and protocols suggested by the forensic sciences community. ${ }^{[2]}$

Dental EW, working either privately or appointed by a court, has defined responsibilities and is subjected to civil or criminal proceedings (depending on the judicial system) if found wanting, keeping in mind that there are significant differences regarding the requirements of becoming eligible to be a dental EW in different legal systems.

The medicolegal consultation of the economic (pecuniary) and noneconomic (nonpecuniary) damages requires a specific training in medicolegal matters as well as an awareness of the inherent pitfalls. Several years of professional experience in dentistry is not considered enough to perform a medicolegal or a forensic dentistry consultation. This is the reason why forensic dentistry community should be aware of the differences in the requirements to become eligible as an EW in court among different judicial systems. Similarities and differences can help in finding the best criteria to become eligible as an EW in court and prevent spontaneous involvement of dentists without a sound forensic and law background, in both civil and criminal cases. ${ }^{[3]}$

\section{Legal Systems}

Existing legal systems today, although divers, are generally based on one of the four following basic systems: common law, civil law, statutory law, religious law, or combinations of these ${ }^{[4]}$ However, the legal system of each country is shaped by its unique history and so incorporates individual variations.

\section{Common law}

It is developed by judges, courts, and similar tribunals, stated in decisions that nominally decide individual cases but that in addition have precedential effect on future cases ${ }^{[5]}$ In cases where the parties disagree on what the law is, a common law court looks to past precedential decisions of relevant courts. If a similar dispute has been resolved in the past, the court is usually bound to follow the reasoning used in the prior. If, however, the court finds that the current dispute is fundamentally distinct from all previous cases, judges have the authority and duty to resolve the issue. Resolution of the issue in one case becomes precedent for future courts.

A "common law system" is a legal system that gives great precedential weight to common law. $\cdot^{[6-8]}$ Common law systems originated during the Middle Ages in England and from there propagated to the colonies of the British Empire. Today, one-third of the world's population live in common law jurisdictions or in systems mixed with civil law.

\section{Civil law}

Civil law is also known as civilian law, or Roman law. It is a legal system that originated in Europe, intellectualized within the framework of late Roman law, and whose most prevalent feature is that its core principles are codified into a referable system which serves as the primary source of law. ${ }^{[4]}$ While the concept of codification dates back to the Code of Hammurabi in Babylon ca. 1790 BC, modern civil law is derived from the Codex Justinianus AD 529, but heavily overlaid by Napoleonic, Germanic, canonical, feudal, and local practices, ${ }^{[9]}$ as well as doctrinal strains such as Canon law and Islamic law, ${ }^{[10,11]}$ codification, and legal positivism.

In civil law, there is a conceptual difference between a statute and a codal article where codal articles deal in generalities in brief, which stands at odds with statutory schemes which are often very long and very detailed.

Civil law today, in theory, is interpreted rather than developed or made by judges. Only legislative enactments (rather than legal precedents, as in common law) are considered legally binding.

Both civil and common law systems can be considered the most widespread in the world; civil law because it is the most widespread by landmass and common law because it is employed by the greatest number of people.

\section{Statutory law}

Also known as statute law, it is a written law set down by a body of legislature or by a singular legislator (in the case of an absolute monarchy). ${ }^{[12,13]}$

\section{Religious law}

Religious law refers to ethical and moral codes taught by religious traditions. Though the methodology used varies, religious law could be Christian (canon law), Islamic (sharia), Jewish (Halakha), or Hindu. ${ }^{[14]}$ The use of Jewish and Halakha for public law has a static and unalterable quality, precluding amendment through legislative acts of government or development through judicial precedent; Christian Canon law is more similar to civil law in its use of codes; and Islamic Sharia law (and Fiqh jurisprudence) is 
Table 1: Summary of the difference between systems in expert witness requirements in Brazil, Croatia, Indonesia, Italy, Saudi Arabia, and the United Kingdom

\begin{tabular}{|c|c|c|c|c|}
\hline Country & Legal system & Requirements to be EW & How to become EW & Training to be EW \\
\hline Brazil & Civil law & $\begin{array}{l}\text { Registered at the professional dental order or chamber } \\
\text { Pass a theoretical and physical examination }\end{array}$ & Appointed by police & $\begin{array}{l}\text { No specific educational } \\
\text { process is required }\end{array}$ \\
\hline Croatia & Civil law & $\begin{array}{l}\text { Have Croatian, EU state, or another signatory State of } \\
\text { the European Economic Area citizenship } \\
\text { Medically fit } \\
\text { Completed a degree at an appropriate school } \\
\text { Worked in the profession (5-10 years depending on } \\
\text { background degree) } \\
\text { To have a contract of liability insurance in order to } \\
\text { operate as a permanent EW }\end{array}$ & $\begin{array}{l}\text { Submitting an } \\
\text { application to the } \\
\text { president of the } \\
\text { county court or } \\
\text { commercial court }\end{array}$ & $\begin{array}{l}\text { Vocational } \\
\text { training (both a } \\
\text { theoretical part and a } \\
\text { practical part) }\end{array}$ \\
\hline Indonesia & $\begin{array}{l}\text { Civil law system, intermixed } \\
\text { with customary law and the } \\
\text { Roman Dutch law }\end{array}$ & $\begin{array}{l}\text { Indonesian citizenship and residence in Indonesia. } \\
\text { Special technical competence in a specific discipline } \\
\text { Registered to the professional medical/dental order } \\
\text { A clear criminal record } \\
\text { Moral quality/high ethical standard }\end{array}$ & $\begin{array}{l}\text { Appointed by police, } \\
\text { prosecutor, judge, or } \\
\text { lawyer }\end{array}$ & $\begin{array}{l}\text { No specific educational } \\
\text { process is required }\end{array}$ \\
\hline Italy & Civil law & $\begin{array}{l}\text { Italian citizenship and residence in the court province } \\
\text { Special technical competence in a specific discipline } \\
\text { Registration to the professional medical/dental order } \\
\text { A clear criminal record certificate } \\
\text { Moral quality (high ethical standards) }\end{array}$ & $\begin{array}{l}\text { Submitting an } \\
\text { application to the } \\
\text { president of the } \\
\text { county court or } \\
\text { commercial court }\end{array}$ & $\begin{array}{l}\text { No specific educational } \\
\text { process is required }\end{array}$ \\
\hline $\begin{array}{l}\text { Saudi } \\
\text { Arabia }\end{array}$ & $\begin{array}{l}\text { Religious law supplemented } \\
\text { by articles and codes issued } \\
\text { by Royal Decree }\end{array}$ & $\begin{array}{l}\text { Have a valid registration from the Saudi Commission } \\
\text { for Health Specialties (in Forensic sciences, this could } \\
\text { only be a diploma, a master's degree or a fellowship) } \\
\text { Have a clear criminal record certificate } \\
\text { Have a high moral quality } \\
\text { Be a male }\end{array}$ & Appointed by court & $\begin{array}{l}\text { No specific educational } \\
\text { process is required }\end{array}$ \\
\hline $\begin{array}{l}\text { The United } \\
\text { kingdom }\end{array}$ & $\begin{array}{l}\text { Common law (England, } \\
\text { Wales, and Northern Ireland) } \\
\text { and pluralistic system (civil } \\
\text { and common) in Scotland }\end{array}$ & $\begin{array}{l}\text { Registered with the GDC } \\
\text { Have a clear criminal record certificate } \\
\text { Have a high moral quality } \\
\text { To have indemnity cover insurance }\end{array}$ & $\begin{array}{l}\text { Appointed by either } \\
\text { prosecution or the } \\
\text { defense }\end{array}$ & $\begin{array}{l}\text { No specific educational } \\
\text { process is required }\end{array}$ \\
\hline
\end{tabular}

GDC: General Dental Council, EW: Expert witness

based on legal precedent and reasoning by analogy (Qiyas) and is thus considered similar to common law. ${ }^{[15]}$

The main kinds of religious law are Sharia in Islam, Halakha in Judaism, and canon law in some Christian groups. In some cases, these are intended purely as individual moral guidance, whereas in other cases, they are intended and may be used as the basis for a country's legal system. The latter was particularly common during the Middle Ages.

In this work, the authors investigated the judicial systems regarding the appointment of dental EWs in Brazil, Croatia, Indonesia, Italy, Saudi Arabia, and the United Kingdom [Table 1], in order to marshal knowledge toward harmonization and the attainment of best practice. This premise acknowledges the fact that forensic odontology must encompass the necessity for robust systems of audit and accreditation for it to be accepted as an "evidence-based" forensic discipline.

\section{Brazil}

\section{Legal system}

It is derived from Portuguese, French, Italian, and
German civil law and is based on statutes and partly and more recently, súmula vinculante (stare decisis). The Federal Constitution, in force since October 21, 1988, is the supreme law of the country and is characterized by its rigid written form. The Constitution organizes the country as a Federative Republic, formed by the indissoluble union of the states and municipalities and of the Federal District. The 26 federate states have powers to adopt their own constitutions and laws, but their autonomy is limited by the principles established in the Federal Constitution.

Legal requirements for becoming expert witness In the Brazilian judicial system, the dental EW is framed in three different and concomitant source laws. First, the Brazilian Federal Law, number 5.081, of August 24, 1966, ${ }^{[4]}$ which regulates the practice of dentistry, establishes:

"Article 2 - the practice of dentistry in the national territory is only allowed to the dentist enabled by official or recognized high school or college, after registration of diploma in the Board of Higher Education, the National Service for Supervision of Dentistry, in the State Health Department and in the Regional Dental Council (...)." 
Furthermore, Article 6 officially allows any graduated dentist to directly perform forensic assessment: "IV- to proceed with legal expertise in forensic dentistry at civil, criminal, labor forum and administrative area; IX - to access neck and head, in autopsy cases, whilst exercising the role of forensic dentist."

Second, the resolution of the Federal Council of Dentistry, number 185, of April 26, 1993, ${ }^{[16]}$ recognizes forensic dentistry as a specialization in dentistry: "Article 54. Forensic Dentistry is the specialty that aims to research psychic, physical, chemical and biological phenomena that can reach or have reached the man, alive, dead or bones, and even fragments or traces, resulting partial or total/reversible or irreversible injuries."

Article 55 of the same law enlists the areas of responsibility of a dental EW:

a. Human identification

b. Expertise in civil, criminal, and labor laws

c. Expertise in the administrative area

d. Expertise, evaluation, and planning labor injuries

e. Forensic anthropology

f. Preparation of records, reports, and opinions and certificates

g. Legal dental traumatology

h. Forensic ballistics

i. Logistics expertise in the alive, the dead, whole, or in human remains

j. Expertise in related traces, including staining or liquids from the oral cavity or present in it

k. Imaging examinations for forensic purposes

1. Dental ethics

m. Dental legal guidance for the professional exercise

n. Image examinations for dental-legal purposes.

Dental forensic involvement in civil cases, summarized by Silva, ${ }^{[17]}$ is as follows:

a. Reimbursement of damage (malpractice, face lesions from accident, or aggression with teeth involvement)

b. Litigation on professional fees when there is no agreement

c. Paternity exclusion: when the analysis of DNA is not possible, a dentist is asked to analyze dental arches to investigate dominant genetic effects transmitted to the oral cavity

d. Age estimation for adoption of minors

e. Evaluation of dental equipment

f. According to the same author, the roles in the criminal skills area are:

g. Identification of perpetrators in crimes with bite marks

h. Skull assessment for human identification

i. Dental/face traumatology

j. Age dental estimation

k. Examination of biological stains (for differential diagnosis among saliva, sperm, and vaginal mucus)

1. Examination of drunkenness (through saliva).
Training needed to become an expert witness

To become an EW in court, dentists have to pass a theoretical and physical examination, and having passed this examination, they can be appointed in police investigation or judicial proceedings, ${ }^{[18]}$ but no specific educational process is required.

On this issue, the criminal procedure code merely states: ${ }^{[19]}$ "Article 159. The examination of corpus delicti and other examinations will be conducted by official expert witness who holds a degree."

Besides, the Code of Civil Procedure, Article 145, states that the official EW must be registered to the professional Dental Order or Chamber.

\section{Croatia}

\section{Legal system}

It is largely influenced by German and Austrian law systems. It is significantly influenced by the Civil Code of the Austrian Empire (1811), known in Croatia as Opći građanski zakon (General Civil Law). It was in force from 1853 to 1946, with some provisions still applying in the modern day. ${ }^{[20]}$

\section{Legal requirements for becoming an expert witness}

In Croatia, the Ministry of Justice requires a specific education process in order to become a permanent EW. In order to be appointed as a permanent EW, the following five conditions must be fulfilled:[21,22]

1. To have Croatian citizenship

2. To have the citizenship of a member state of the European Union or another signatory State of the European Economic Area

3. To be medically fit to perform the permanent tasks of an EW

4. To have completed a degree at an appropriate school and have worked in the profession as follows: at least 5 years (if completed undergraduate and graduate university studies, or undergraduate university study and specialist graduate professional study, or professional study and specialist graduate professional study), or at least 8 years (if completed appropriate undergraduate university study or professional study). Court testimony, in exceptional cases, could be carried out by a professional with at least 10 years' work experience in the profession, after having completed suitable high school education

5. To have a contract of liability insurance in order to operate as a permanent EW.

A person cannot be appointed as a permanent EW if he/ she has a barrier to entry into the civil service, or has been pronounced a risk to security as a legal consequence of a conviction, or has been banned from pursuing the 
profession at the time of requesting an appointment as a permanent EW. ${ }^{[22]}$

The ability of a candidate to perform the duties of a permanent EW should be determined on the basis of reports on vocational training conducted by a mentor who is a permanent EW in an appropriate discipline and under whose supervision the candidate must complete at least five expert testimonies, findings, and opinions. ${ }^{[22]}$ The procedure for the appointment of a permanent EW starts with submitting an application to the President of the County Court or Commercial Court (depending on the applicant's place of residence). The application should be accompanied by a list of the candidate's published scientific and professional papers. Before submitting the application, the candidate should pass a vocational training program.

\section{Training needed to become an expert witness}

Specialists in legal medicine with a valid license of Croatian Medical Chamber are not obliged to complete any training. ${ }^{[21]}$ The County or Commercial Court refers a request from an applicant to the Croatian Chamber of Dental Medicine (CCDM) to nominate a mentor who will conduct the training of the candidate. The Executive Board of CCDM selects a mentor and informs the Court. A mentor will be a dentist who is appointed as a permanent EW of the County or Commercial Court, who is a member of good standing with the CCDM, who has provided at least five expertise testimonies independently, and who has the same or higher level of educational degree as the candidate. ${ }^{[22]}$

The training program includes both a theoretical and a practical part. In the theoretical part, the vocational training mentor introduces the candidate to the professional dental literature and all legal and regulatory acts relating to the judicial expertise for which the candidate is being trained. The practical part of professional training covers all related data collection, access to the trial, etc.

Under the mentor's supervision, the candidate is required to complete at least five expert testimonies and make findings and opinions. After the training has been completed, the mentor compiles a report on the effectiveness and qualifications of the candidate to present to the Executive Committee of the CCDM.

The candidate bears all costs of performing the professional training (HRK8000 + VAT which is approximately $€ 1100)$. As a compensation for providing professional training, the mentor is entitled to the amount of HRK2500 (approximately €350), which is paid from the abovementioned costs. ${ }^{[22]}$

Prior to appointment as a permanent EW, the candidate is obliged to submit proof of compulsory liability insurance that meets the demands for damages that could result from his/her work as a permanent EW. The candidate must be covered during the entire period in which he/she is appointed as a permanent EW. The minimum sum insured is at least HRK200,000. After these requirements have been met, the president of the court considers the candidate's request and issues the final decision. ${ }^{[21]}$

\section{Indonesia}

\section{Legal system}

It is based on a civil law system, intermixed with customary law and the Roman Dutch law. Before the Dutch colonization in the $16^{\text {th }}$ century, indigenous kingdoms ruled the archipelago independently with their own custom laws, known as adat. Foreign influences from India, China, and Arabia have not only affected the culture, but also weighed in the customary adat laws. Aceh in Sumatra, for instances, observes their own Sharia law, while Toraja ethnic group in Sulawesi are still following their animistic customary law.

Dutch presence and subsequent occupation of Indonesia for 350 years have left a legacy of Dutch colonial law, largely in the Indonesian civil code. Following the independence in 1945, Indonesia began to form its own modern Indonesian law, not developing it from scratch, but modifying precepts of the existing laws. Dutch legal decisions maintain some authority in Indonesia through application of the concordance principle. In the law of Indonesia, three components co-exist currently: the customary law (known locally as Adat), DutchRoman law; and modern Indonesian law.

\section{Legal requirements for becoming an expert witness}

In Indonesian judicial system, there is no specific educational process required by the court for appointment as an EW. Usually, a dentist or a pathologist is appointed as an expert by the police, the prosecutor, the judge, or simply the lawyer.

To be included in the list of EWs before the court, the following requirements are needed:

1. Indonesian citizenship and residence in Indonesia

2. Special technical competence in a specific discipline (documents as a proof, according to the standard of EW education: The Standard of education on doctor and dentist profession is fit on the rule of the Act on National Education System, article 7 (2), Indonesian Medical Practice Act number 29, 2004) ${ }^{[23]}$

3. Register to the professional medical/dental order (register in the association/organization and legally approved from the government/origin country) $)^{[24,25]}$

4. A clear criminal record certificate/letter of approval from the police headquarters ${ }^{[26]}$

5. Moral quality/high ethical standard (approval letter by the Indonesian Medical Association or from Indonesian Dental Association and/or from the Association of Forensic Sciences, Indonesia). 
The state of Republic of Indonesia is a nation governed by law based on the Pancasila and the Constitution of 1945, which upholds human rights and guarantees that all its citizens shall have equal status in law and government and shall be obligated to respect law and government without exception. EW in the Indonesian Law of Criminal procedure is framed in Article 186: Expert testimony is what an experts states at trial. Article 1 (28): Expert testimony is information provided by a person who has special expertise on matters require to elucidate a criminal case for purposes of examination. Article 179 (1): any person who is asked for his opinion as a doctor forensic medicine or as a physician or other expert shall be obligated to give expert testimony in the interest of justice. (2) All the afore said provisions with the regard to witnesses shall also apply to those who give expert testimony provided however that they shall take an oath or affirmation to testify to the truth and to the best of their knowledge in their field of expertise.

In the Rule of Police headquarter number 14, 2012 (chapter I, common rule, Article 12), Expert Testimony is the testimony that is given by a person who has a special expertise to make the case clear. ${ }^{[27]}$

In Indonesia, an EW in court is someone who has the knowledge and experiences more than the average person and will respect ethical concerns on the best scientific method based on the factual information and not simply his/her opinion. The EW is asked to support any technical conclusion using simple words that can be understood by the parties in the court. ${ }^{[28]}$

In Indonesian Law of Criminal Procedure, an EW cannot refuse to testify without any valid reason and can be confined in the state or house arrest for at most 14 days. False testimony under oath is punishable by a maximum imprisonment of 7 years. ${ }^{[27]}$

Training needed to become an expert witness No special training is required to be an EW.

\section{Italy}

\section{Legal system}

It has a plurality of sources of production. These are arranged in a hierarchical scale, under which the rule of a lower source cannot conflict with the rule of an upper source (hierarchy of sources).

The Constitution of 1948 is the main source. The Italian Civil Code is based on codified Roman law with elements of the Napoleonic civil code and the civil code of Germany Bürgerliches Gesetzbuch (BGB). The civil code of 1942 replaced the original one of 1865 . The penal code ("The Rocco Code") was also written under fascism (1930).
Both the civil code and the penal code have been modified in order to be in conformity with the current democratic constitution.

Legal requirements for becoming an expert witness In the Italian judicial system, there is no specific educational process required by the court for appointment as an EW. A dentist who wishes to apply to become a registered EW has to fulfill the following requirements and have:

1. Italian citizenship and residence in the court province

2. Special technical competence in a specific discipline (documents as proof)

3. Registration to the professional medical/dental order

4. A clear criminal record certificate

5. Moral quality (high ethical standards).

Moral quality is not only identified as absence of criminal convictions or proceedings, but also the presence of a highly ethical way of life both in private and professional environments. The application is evaluated by a committee consisting of the court president for the geographical area of the candidate, the province prosecutor attorney, and a representative of the professional order of the candidate.

These committees may evaluate applications differently in different locations.

Some consider a degree in dental medicine/science sufficient to demonstrate the "special technical competence" requested by law (Article 61 of the civil code). However, in the Court of Rome, the candidate will be eligible only with a total of more than 30 points, calculated from professional experience in complex cases, publications of articles, monographs, books, and presentations as a lecturer or a speaker in universities, institutes, or specialization courses. ${ }^{[29]}$ Finally, a reasonable period of 5 years of professional work is also required.

Every court holds an additional list of EWs for criminal cases. In this case, an EW must have 5 years of enrollment on the civil cases' list. The lists of EWs are revised every 4 years. These are the only lists from which the judges may choose an EW unless there are none available or there is a possible conflict of interest. If that is the case, the judge can appoint an EW from other court's province.

In the Italian judicial system, rights and duties of an EW are stated under the law and ethics provisions relating to medicolegal consultation that is defined by Article 62 of Medical Code of Ethics ${ }^{[30]}$ and summarized as follows:

1. The activity of the medical examiner requires high moral standing and professional awareness regarding the ethical, legal, and deontological responsibilities involved and an awareness in avoiding any kind of influence or pressure from external technical resources

2. The taking on of any case must correspond with an 
adequate medicolegal and scientific knowledge so that all judicial requirements of the case under examination may be fulfilled (...)

3. In particularly complex cases, the medical examiner may seek consultancy from a colleague who has a proven history of experience and competence in the involved discipline. The medical examiner in charge assumes full professional responsibility for such consultancy

4. General practitioners may not exercise medicolegal responsibilities (...) in cases where they have directly assisted or treated, or those in which there exists an employment contract with the health establishment involved in the judicial enquiry

5. Consultants should interpret the scientific evidence, which has been made available by the claimant, with both objectivity and logical scientific reasoning as well as with a prudent evaluation relative to the conduct of the involved individuals

6. The completion of unlawful medicolegal services (...) constitutes not only as an illegal offence punishable by law, but also as indecorous conduct toward the profession itself.

Training needed to become an expert witness No special training is required to be an EW.

\section{Saudi Arabia}

\section{Legal system}

Saudi Arabia practices religious law based on Sharia, which is derived from the Holy book (Qur'an), the traditions of Prophet Muhammad (Sunnah), and Islamic scholarly consensus developed after the death of the Prophet Muhammad's death.

Many laws are left to the interpretation by judges, which are influenced by the texts of the literalist Hanbali school of Islamic jurisprudence that were put 200 years after the foundation of Islam. Uniquely in the Muslim world, Sharia has been adopted by Saudi Arabia in an uncodified form. This, and the lack of judicial precedent, has resulted in considerable uncertainty in the scope and content of the country's laws. The government therefore announced its intention to codify Sharia in 2010, but this is yet to be implemented. Sharia has also been supplemented by articles and codes issued by Royal Decree covering modern issues.

The current Saudi court system was created by King Abdul Aziz, who founded the Kingdom of Saudi Arabia in 1932, and was introduced to the country in stages between 1927 and 1960. It comprises general and summary Sharia courts, with some administrative tribunals to deal with disputes on specific modern regulations. Trials in Saudi Arabia are bench trials. Courts in Saudi Arabia observe few formalities, and the country's first criminal procedure code, issued in 2001, has been largely ignored. King Abdullah, in 2007, introduced a number of significant judicial reforms, although they are yet to be fully implemented.

In Saudi Arabia, the Ministry of Justice's law of criminal procedure, article number $172,{ }^{[31]}$ states that "the Court may assign one or more experts to advice on any technical questions related to any case. The expert shall provide the court, within the prescribed time, with a written report stating his opinion. Litigants may obtain a copy of that report. If the litigants, witnesses or either of them do not understand Arabic, the court may seek the assistance of interpreters."

\section{Legal requirements for becoming an expert witness}

Forensic EW should have the following qualifications:

1. Have a valid registration from the Saudi Commission for Health Specialties (in forensic sciences, this could only be a diploma, a master's degree, or a fellowship)

2. Have a clear criminal record certificate

3. Have a high moral quality (high ethical standards in both professional and personal lives)

4. Be a male.

Training needed to become an expert witness There is no training in forensic odontology in Saudi Arabia. All the EW candidates are employed by the Department of Forensic Medicine of the Ministry of Health, Riyadh, Saudi Arabia. The department grants fellowship training in forensic sciences to medical doctors with a brief overview on forensic odontology, but there are no dentists. All forensic doctors have to pass a final verifying examination. ${ }^{[32]}$

After enrollment in the Department of Forensic Medicine, there is a defined pathway to follow in the process to become accepted an EW:

a. In the $1^{\text {st }}$ year, the applicant will only observe cases, including documentation and the process of the court procedures. Theoretical training and examinations will be carried out in this $1^{\text {st }}$ year

b. In the $2^{\text {nd }}$ year, the applicant will be subject to vocational training conducted by a mentor in an appropriate discipline. There will be no case involvement

c. In the $3^{\text {rd }}$ year and under the mentor's full and direct supervision, the applicant will be assigned some cases

d. In the $4^{\text {th }}$ year, the applicant will be assigned simple cases to do on his/her own behalf

e. In the $5^{\text {th }}$ year, the applicant will be expected to take on any case and will then be considered, or not, as an EW registered within the Ministry of Health.

An annual written and oral examination is necessary in order to be promoted from any level to the following. The successful candidate will be conferred with a Saudi Specialty Certificate in Forensic Medicine on the completion of all academic and practical requirements and of being successful in meeting the requirements of the final examination. 
Any court requiring a forensic expert will usually contact the Ministry of Health, which in turn will appoint an EW. The registered EW is obliged to accept the case appointed to him unless there is a conflict of interest or he lacks the specific competence/knowledge.

\section{United Kingdom}

\section{Legal system}

The United Kingdom has three legal systems: English law, which applies to England and Wales; Northern Ireland law, which applies to Northern Ireland; and Scottish law, which applies to Scotland. English law and Northern Irish laws are based on common law antecedents whereas Scottish law has an ancient base in Roman law and is a pluralistic system based on civil law principles, with common law elements dating back to the Middle Ages.

There are no specific educational requirements in the United Kingdom to become an EW. However, it is not the court that appoints the EW, but one or other of the legal parties representing the prosecution or the defense. The court acts solely as an impartial referee and facilitator between the two parties.

In the United Kingdom, an EW is defined as "An expert (....) who by virtue of education, training, skill, or experience, is believed to have expertise and specialized knowledge in a particular subject beyond that of the average person, sufficient that others may officially and legally rely upon the witness's specialized opinion about an evidence or fact issue within the scope of his expertise, referred to as the expert opinion, as an assistance to the fact-finder."[33]

\section{Legal requirements for becoming an expert witness}

The duties and responsibilities of an EW in the United Kingdom were established by Mr. Justice Cresswell in the case of "National Justice Compania Naviera SA versus Prudential Assurance Company Limited 1993" (also known as the "Ikarian Reefer" case). ${ }^{[34]}$ The duties and responsibilities of an EW were clearly defined in this case:

1. Expert evidence presented to the court should be, and should be seen to be, the independent product of the expert uninfluenced as to form or content by the exigencies of litigation

2. An EW should provide independent assistance to the court by the way of objective unbiased opinion in relation to matters within his expertise

3. An EW witness should state the facts or assumptions upon which his opinion is based. He should not omit to consider material facts which could detract from his concluded opinion

4. An EW should make it clear when a particular question or issue falls outside his expertise

5. If an expert's opinion is not properly researched because he considers that insufficient data is available, then this must be stated with an indication that the opinion is no more than a provisional one

6. If the expert cannot assert that the report contains the truth, the whole truth and nothing but the truth, without some qualification, that qualification should be stated in the report

7. If, after exchange of reports, an EW changes his view on a material matter having read the other side's expert's report, or for any other reason, such change of view should be communicated (though legal representatives) to the other side without delay and (where appropriate) to the court

8. Where expert evidence refers to photographs, plans, calculations, analyses, measurements, survey reports, or other similar documents, they must be provided to the opposite party at the same time as the exchange of reports.

Dentistry has many disciplines and dental EWs would normally confine their expertise to their own specialty, for example, restorative dentistry, periodontics, geriatric dentistry, and forensic dentistry. The practicing EW would also, as a matter of course, be registered with the General Dental Council (GDC) as a mandatory requirement of competence and untainted criminal and moral status although it should be said that the GDC currently does not recognize forensic dentistry as a specialty in the UK. ${ }^{[35]}$ The EWs in the UK would also have indemnity cover insurance for their own protection.

\section{Training needed to become an expert witness}

Until recently, several postgraduate (PG) courses leading to a recognizable PG qualification in forensic dentistry have been available in the United Kingdom. However, from September 2013, this situation has changed with just one remaining provider of PG education in forensic dentistry in the United Kingdom (University of Dundee).

The majority of dentists in the UK, with aspirations of becoming recognized as an EW in forensic odontology, join the British Association for Forensic Odontology (BAFO). ${ }^{[36]}$ The mission statement of BAFO is "BAFO exists to encourage education and good practice in forensic odontology and to accredit, to review performance and to mentor practitioners in forensic odontology." BAFO was established as the representative and accreditation body for forensic odontology in the UK. However, it should be noted that BAFO has no overriding power to restrict the practice of forensic odontology among members and nonmembers. BAFO also has a mentoring system in place to ensure support for new members to achieve their aspirations and is active in providing PG education seminars.

\section{Discussion}

Clinical dentistry and dental law are two different disciplines 
although both are specifically related to dentistry. As an EW, a dentist has precise responsibilities, and if found wanting, can be subjected to either civil or criminal proceedings depending on judicial system ${ }^{[1,2,36]}$ The role of an EW is not just writing reports, but involves much more.

To fulfill their duties adequately, it is vital that an EW is involved in the legal and/or forensic field in order to keep up to date with the current thinking and developments, and to attend relevant continuous educational training in conjunction with lawyers, medicolegal doctors, and other forensic experts.

The Croatian judicial system seems keen to promote an appropriate level of education and experience in the candidate's medicolegal field prior to registration on the EW list. On the other hand, the Brazilian, British, Indonesian, and Italian judicial systems seem to rely on the principle that, if an applicant is a dental professional, there is an implicit inference that he/she has enough basic training to undertake further PG studies on the pathway to becoming accepted as an EW in his/her own right. It is ethically presumed that an EW will have a medicolegal knowledge beyond the average of clinicians.

In Saudi Arabia, there are no PG forensic odontology courses and the unique fellowship course is targeted toward general forensic medicine.

However, very few dental schools provide either forensic odontology or medicolegal dentistry as a part of their curricula. This unique situation makes the EW either general dentists with no special training or forensic medicine professionals doing the dentists' job.

In Brazil, Indonesia, and Saudi Arabia, forensic dentistry is still at an early stage of becoming accepted as a recognized forensic discipline.

Following the acceptance of the Internet and marketing imperatives, the access and exchange of information relevant to forensic dentistry has improved, but more courses and training workshops are necessary. This is against the background of the necessity to identify both the deceased persons and the perpetrators of bite mark injuries, which are increasing aspects of the forensic odontologist.

Globally, there is an increasing demand for identification of both living and deceased persons because of escalating criminal activity and immigration. Unfortunately, most PG courses are concentrated in big cities, effectively excluding other interested dentists who happen to live away from the large cities.

The comparison of so many different judicial systems reveals the importance of quality control and quality assurance in the registration of EWs in courts and highlights the need for collaboration with medicolegal doctors. Civil and criminal cases involving any aspect related to dentistry or odontology should ideally require medicolegal doctors to work in collaboration with an experienced dentist who is an EW so that medical doctors are not providing advice outside their area of expertise.

\section{Conclusion}

Dentists without any specialist training in forensics and law should refrain from any involvement in civil or criminal cases, leaving the provision of expert testimony to those odontologists qualified in forensic sciences and medicolegal doctrines. The authors also believe that, as for forensic pathology and legal medicine, forensic odontology and legal dentistry should become an official university specialization course and not just a master of a PG degree. This would help to guarantee quality control and quality assurance issues in all areas of involvement of forensic dentists.

\section{Financial support and sponsorship}

Nil.

\section{Conflicts of interest}

There are no conflicts of interest.

\section{References}

1. Nuzzolese E, Čuković-Bagić I. Expert witnesses in dentistry: A comparison between Italy and Croatia. Forensic Odontostomato 2012; Nov 30; 30 Suppl 1:29-39. Available from: http://www. iofos.eu/Journals/JFOS\%20sup1_Nov12/IDEALS\%204-97.pdf. [Last accessed on 2013 May 01].

2. De Leo $\mathrm{D}$, Montagna $\mathrm{F}$. La responsabilità del consulente tecnico. In: Montagna F, De Leo D, Carli OP, editors. La Responsabilità Nella Professione Odontoiatrica. ANDI Verona, Ed. Promoass; 1999. p. 309-13.

3. Nuzzolese E, Montagna F, Di Nunno N, De Leo D. The medicolegal consultation and the responsibility of the dentist expert / CTU odontoiatra. Minerva Med Leg 2011 September;131(3):67-73.

4. Wood PR. Law and practice of international finance. Principles of International Insolvency. $2^{\text {nd }}$ ed. London: Sweet and Maxwell; 2007.

5. Bryan AG. A Dictionary of Modern Legal Usage. $2^{\text {nd }}$ Revised ed. New York: Oxford University Press; 2001. p. 177.

6. Garner BA. Black's Law Dictionary-Common Law. $10^{\text {th }}$ ed. Eagan, Minnesota: Thompson West;2014. p. 334, 2.

7. Bryan AG. A Dictionary of Modern Legal Usage. $2^{\text {nd }}$ Revised ed. New York: Oxford University Press; 2001.

8. Arnold-Baker C. The Companion to British History, S.V. “English Law". London: Loncross Denholm Press; 2008. p. 484.

9. Fromont M. Grands Systèmes de Droit Étrangers. $4^{\text {th }}$ ed. Paris: Dalloz; 2001. p. 8.

10. Gamal Moursi B. "Islamic Law: Its Relation to Other Legal Systems". (The American Journal of Comparative Law. Vol. 26. Salt Lake City, Utah: Proceedings of an International Conference on Comparative Law (Spring 1978); 1977. p. 24-5, 187-98, 196-8.

11. John AM. The Islamic Origins of the Common Law. North Carol Law Rev 1999;77:1635-739. 
12. Fundamental Law of Vatican City State, Art. $1 \S 1$. Available from: https: //ipfs.io/ipfs/QmXoypizj W3WknFiJnKLwHCnL72vedxjQkDDP1mXWo6uco/wiki/ Fundamental_Law_of_Vatican_City_State.html. [Last accessed on 2018 Jan 30].

13. Barzilai G. Law and Religion. Burlington: Ashgate; 2007. Available from: http://law.haifa.ac.il/images/documents/ Law\%20and\%20 Religion_intro.pdf. [Last accessed on 2018 Jan 30].

14. Mahmoud AE. Islamic Finance: Law, Economics, and Practice. New York: Cambridge University Press; 2006. p. 16. Available from: http://iugc.yolasite.com/resources/Reference $\% 20$ Book $\% 20$ $04 \% 20-\% 20$ Islamic $\% 20$ finance, $\% 201$ aw $\% 20$ economics $\% 20$ and $\% 20$ practice, $\% 20 \mathrm{M} . \% 20 \mathrm{El} \% 20 \mathrm{Gamal}$.pdf. [Last accessed on 2018 Jan 30].

15. Brasil. Lei Federal $n^{\circ} 5.081$, de 24 de Agosto de 1966. Regula o Exercício da Odontologia. Legislação Federal. Available from: http://www.planalto.gov.br/ccivil_03/leis/15081.htm. [Last accessed on 2013 Mar 16; Last updated on 2012 Jul 08].

16. Brasil. Resolução CFO-185/93, de 26 de abril de 1993. Aprova a Consolidação das Normas para Procedimentos nos Conselhos de Odontologia e revoga a Resolução CFO-155/84. Available from: http://www.croba.org.br/documentacao/RESOLUCAO_ CFO_185_93.pdf; http://www.cfo.org.br. [Last accessed on 2013 Mar 16; Last updated on 2012 Jul 08].

17. Silva M. Da. Compêndio de Odontologia Legal. São Paulo: Medsi Editora; 1997. p. 490.

18. Couto RC. Perícias em Medicina and Odontologia Legal. Rio de Janeiro: MedBook; 2011. p. 680.

19. Brasil. Código de Processo Penal. Decreto-Lei N 3.689, de 3 de outubro de 194. Disposições Gerais do Exame do Corpo de Delito, e das Perícias em geral. Available from: http://www.planalto.gov. br/ccivil_03/decreto-lei/del3689compilado.htm. [Last accessed on 2013 Mar 16; Last updated on 2012 Jul 08].

20. Croatian Association of Court Expert Witnesses-pravilnik o stalnim sudskim vještacima. Available from: http://www.sudski-vjestaci. $\mathrm{hr} /$ clanci/aktualno/pravilnik-o-stalnim-sudskimvjestacima/ pravilnik-o-stalnim-sudskim-vjestacima-37.html. [Last accessed on 2013 Mar 19; Last updated on 2012 Jul 08].

21. Croatian Association of Court Expert Witnesses-pravilnik o Izmjenama i Dopunama Pravilnika o Stalnim Sudskim vještacima. Available from: http://www.sudskivjestaci.hr/clanci/aktualno/ pravilnik-o-stalnim-sudskim-vjestacima/pravilnik-o-izmjenamai-dopunama-pravilnika-o-stalnimsudskim-vjestacima-49.html. [Last accessed on 2013 Mar 19; Last updated on 2012 Jul 08].

22. Hrvatska Komora Dentalne Medicine-Pravilnik o Načinu Obavljanja Stručne Obuke Kandidata za Stalnog Sudskog Vještaka. Available from: http://www.hkdm.hr/?page=akti-pravilnik8. [Last accessed on 2013 Mar 19; Last updated on 2012 Jul 08].

23. Act No. 29. Indonesian Medical Practice; 2004. Available from: http://www.inamc.or.id/download/UU\%20NO\%2029.rtf. [Last accessed on 2013 Apr 30; Last updated on 2004 Nov 03].
24. Act No. 20, 2003 on Education National System. Available from: http://www.archive.we.dikti.go.id. [Last accessed on 2013 Apr 30; Last updated on 2003 Nov 24].

25. Act No. 14. The Rule of Police Headquarter about Management of Investigation on Criminal Act; 2012. p. 2, 3, 6, 31-2. Available from: http://www.ebookbrowse.com. [Last accessed on 2013 Apr 30; Last updated on 2012 Jun 25].

26. Act No. 8. The Indonesian Law of Criminal Procedure. Ratified in Jakarta; 1981. p. 4, 18-9, 24-6, 28, 32-3, 35-7. Available from: http://www.defensewiki.ibj.org/images/6/62/Indonesia_Law_ of_Criminal_Procedure.pdf. [Last accessed on 2013 Apr 30; Last updated on 2012 Jun 25].

27. Indonesian Association of Forensic Sciences, Ethics on Expert Witness in Indonesia. Available from: http://www.aifi.or.id/ kode-etik.[Last accessed on 2013 Apr 30; Last updated on 2012 Jun 25].

28. Rossetti M. Il CTU. Milano: Giuffrè Ed; 2006. p. 43.

29. Medical Ethical Code 2006-Codice di Deontologia Medica; 2006. Available from: http://www.fnomceo.it/fnomceo/Codice+di+D eontologia+Medica+2006.html? $\mathrm{t}=\mathrm{a} \& \mathrm{id}=3694$ [Last accessed on 2013 May 04; Last updated on 2006 Dec 16].

30. Law of Criminal Procedures, Royal Decree No. (M/39) 28 Rajab 1422 [16 ${ }^{\circ} \mathrm{CT}$ 2001] Umm al-Qura No. (3867) 17 sha'ban 1422. Available from: http://www.saudiembassy.net/about/ country-information/laws/CriminalProcedures2001-1of3. aspx. [Last accessed on 2013 May 04; Last updated on 2001 Nov 03].

31. Saudi Commission for Health Specialties: Training Program for Saudi Specialty Certificate in Forensic Medicine. Available from: http://www.arabic.scfhs.org.sa/new/fellowship_arabia_file/SB-4. pdf. [Last accessed on 2013 May 04; Last updated on 2012 Nov 03].

32. Federal Evidence Review: Federal Rules of Evidence; 2013. Available from: http://www.federalevidence.com/ rules-of-evidence\#Rule702. [Last accessed on 2013 Mar 19; Last updated on 2013 Jan 01].

33. National Justice Compqania Naviera SA v Prudential Assurance Company Limited: (Also known as tge "Ikarian Reefer" case): N[1993] 2 Lloyds Rep 68. Available from: http://www. simplymalaysia.files.wordpress.com/2011/11/national-justicecompania-naviera-sa-v-prudential-assurance-co-ltd.pdf. [Last accessed on 2013 Mar 19; Last updated on 2011 Nov 01].

34. The General Dental Council, 37 Wimpole Street, London, W1G 8DQ. Available from: http://www-gdc-uk.org. [Last accessed on 2013 Mar 19; Last updated on 2013 Mar 19].

35. British Society for Forensic Odontology British Society for Forensic Odontology (BAFO). Available from: http://www.bafo.org uk. [Last accessed on 2013 Mar 19; Last updated on 2013 Mar 19].

36. Kolczynski PJ. How to Be A Successful Expert Witness, ExpertPages.com's Knowledge Base; 1997. Available from: http:// www.expertpages.com/news/how_to_be_a_successful_expert_ wi.htm. [Last accessed on 2012 Sep 23]. 